\title{
KAJIAN HUKUM PERDATA TERHADAP PENGGUNAAN PERJANJIAN TIDAK TERTULIS DALAM KEGIATAN BISNIS
}

\author{
I Wayan Agus Vijayantera \\ Fakultas Hukum Universitas Mahasaraswati Denpasar \\ Email : agus.vije@gmail.com / agus.vije@unmas.ac.id
}

\begin{abstract}
Abstrak
Perjanjian tidak tertulis merupakan perjanjian yang sering digunakan dalam transaksi bisnis pada kalangan masyarakat tradisional. Keberadaan perjanjian tidak tertulis lebih lemah jika dibandingkan dengan perjanjian tertulis khususnya dalam pembuktian ketika terjadi sengketa. Berdasarkan hal tersebut, adapun tujuan penulisan adalah untuk menganalisis keberadaan perjanjian tidak tertulis ditinjau dalam hukum perdata, serta menganalisis keunggulan dan kelemahan pembentukan dan pelaksanaan perjanjian tidak tertulis. Pada pembahasan, perjanjian tidak tertulis merupakan perjanjian yang sah dalam perspektif hukum perdata selama tidak bertentangan dengan Pasal 1320 Kitab Undang-Undang Hukum Perdata. Keberadaan perjanjian tidak tertulis didasarkan pula pada adanya asas kebebasan berkontrak yang memberikan kebebasan para pihak untuk menentukan bentuk perjanjiannya. Perjanjian tidak tertulis memiliki keunggulan berupa efisien waktu yang digunakan untuk mencapai kesepakatan serta penggunaan rasa kepercayaan dalam pembentukan dan pelaksanaan perjanjian, sedangkan kelemahannya terletak pada pembuktian perjanjian ketika terjadi sengketa.
\end{abstract}

Kata Kunci : hukum perdata, perjanjian tidak tertulis, bisnis.

\begin{abstract}
An unwritten agreement is an agreement that is often used in business transactions among traditional communities. The existence of an unwritten agreement is weaker when compared to a written agreement, especially in the evidence when a dispute occurs. Based on this, the purpose of writing is to analyze the existence of unwritten agreements reviewed in civil law, and analyze the strengths and weaknesses of the formation and implementation of unwritten agreements. In the discussion, an unwritten agreement is a valid agreement in the perspective of civil law as long as it does not conflict with Article 1320 of the Civil Code. The existence of an unwritten agreement is also based on the principle of freedom of contract which gives the parties the freedom to determine the form of the agreement. An unwritten agreement has the advantage of being time efficient to reach an agreement and the use of a sense of trust in the formation and implementation of the agreement, while the weakness lies in proving the agreement when a dispute occurs.
\end{abstract}

Keywords: civil law, unwritten agreement, business. 


\section{Pendahuluan}

Manusia dalam kebutuhannya tidak dapat terlepas dalam pergaulan dalam kelompok hidupnya. Sifat manusia yang tidak mampu terpisah dengan lingkungan pergaulan kelompoknya dipaparkan oleh Aristoteles dalam pandangannya bahwa "manusia adalah zoon politicon, yaitu bahwa manusia sebagai makhluk sosial selalu berusaha untuk hidup berkelompok, dan bermasyarakat." 1 Hal ini menunjukkan bahwa manusia pada dasarnya tidak ada yang mampu untuk hidup sendiri.

Orang dalam kesehariannya terikat dengan pihak lain. Melalui perikatan itulah kebutuhannya relatif mudah dipenuhi ketimbang dilaksanakan secara sendirian. Interaksi antar anggota kelompok merupakan pola hidup manusia yang bercorak sebagai zoon politicon. Lewat interaksi sebagai cara memenuhi kebutuhan hidup, sudah tidak mungkin terhindarkan, baik dalam rangka memperoleh kebutuhan sandang, pangan, ataupun papan, dan tidak terkecuali urusan regenerasi sebagai tuntutan alaminya. $^{2}$

Setiap orang dalam memenuhi kebutuhan hidupnya dikatakan bahwa membutuhkan interaksi antara orang yang satu dengan orang lainnya. Contoh bentuk interaksi tersebut yakni dengan melakukan kegiatan bisnis seperti melakukan kegiatan jual beli, sewa menyewa, dan lain sebagainya.

1 Muhamad Sadi Is, 2017, Pengantar Ilmu Hukum, Kencana, Jakarta, h. 79.

${ }^{2}$ H. Moch Isnaeni, 2016, Perjanjian Jual Beli, Refika Aditama, Bandung, h. 1. (Selanjutnya Disebut H. Moch Isnaeni I)
Kegiatan bisnis ini dibutuhkan bagi pelaku bisnis dengan tujuan utama yakni memperoleh pemasukan yang bersifat menguntungkan.

Proses terciptanya kegiatan bisnis jika dilihat dalam hukum perdata, biasanya selalu terdapat perjanjian yang menjadi dasar terlaksananya kegiatan bisnis tersebut baik dengan menggunakan bentuk perjanjian tertulis, maupun perjanjian tidak tertulis yang dikenal pula dengan perjanjian lisan. Melihat pada keberadaan perjanjian tidak tertulis sebagai dasar terbentuknya dan terlaksananya kegiatan bisnis, banyak kegiatan bisnis yang menggunakan bentuk perjanjian tidak tertulis ini.

Perjanjian tidak tertulis pada faktanya lebih cenderung terlihat lemah terutama dalam pembuktiannya ketika terjadi sengketa. Berdasarkan hal tersebut maka menarik untuk melakukan penelitian dengan judul "Kajian Hukum Perdata Terhadap Penggunaan Perjanjian Tidak Tertulis Dalam Kegiatan Bisnis" dengan maksud menganalisis sahnya keberadaan perjanjian tidak tertulis jika dilihat dalam perspektif hukum khususnya hukum perdata, serta memahami keunggulan dan kelemahan dari perjanjian tidak tertulisnganalisis perjanjian tidak tertulis jika dilihat dalam asas-asas hukum perjanjian.

\section{Rumusan Masalah}

Berdasarkan hal-hal yang telah diuraikan dalam latar belakang, adapun yang menjadi rumusan masalah yakni sebagai berikut : 
1. Perjanjian yang dibuat dalam bentuk tidak tertulis ditinjau dalam hukum perdata

2. Keunggulan kelemahan pembentukan pelaksanaan tidak tertulis

\section{Perjanjian yang dibuat dalam bentuk tidak tertulis ditinjau dalam hukum perdata}

Perjanjian dalam hemat kata dapat dimaknai sebagai suatu janji yang diucapkan dan dilaksanakan oleh pihak yang berjanji kepada pihak yang menerima janji. Perjanjian jika dilihat definisinya dalam peraturan perundangundangan ditemukan dalam Pasal 1313 Kitab Undang-Undang Hukum Perdata yang menyatakan bahwa : "suatu perjanjian adalah suatu perbuatan dengan mana satu orang atau lebih mengikatkan dirinya terhadap satu orang lain atau lebih".

Perjanjian dalam Pasal 1313 Kitab Undang-Undang Hukum Perdata tersebut terdapat unsur perikatan sebagaimana dalam kata "mengikatkan dirinya terhadap satu orang lain atau lebih." Perjanjian pada dasarnya merupakan dasar menciptakan suatu perikatan sebagaimana telah dinyatakan secara jelas dalam Pasal 1233 Kitab Undang-Undang Hukum Perdata yakni "Tiap-tiap perikatan dilahirkan baik karena persetujuan, baik karena undang-undang."

Perikatan yang dilahirkan karena persetujuan / perjanjian, maka timbulnya suatu perikatan didahului dengan adanya perjanjian yang dibuat oleh para pihak yang selanjutnya menciptakan hubungan perikatan dengan akibat hukum yang muncul dalam pelaksanaan perjanjian tersebut. Definisi perikatan merujuk dalam pandangan Subekti bahwa perikatan merupakan "suatu perhubungan hukum antara dua orang atau dua pihak, berdasarkan mana pihak yang satu berhak menuntut sesuatu hal dari pihak yang lain, dan pihak yang lain berkewajiban memenuhi tuntutan tersebut" ${ }^{3}$

Hak dan kewajiban para pihak dalam hubungan hukum perikatan tersebut sebagaimana dijabarkan bentuk-bentuk perikatan dalam Pasal 1234 Kitab Undang-Undang Hukum Perdata yang menyatakan “tiap-tiap perikatan adalah untuk memberikan sesuatu, untuk berbuat sesuatu, atau untuk tidak berbuat sesuatu." Perbuatan-perbuatan dalam perikatan tersebut dikaitkan dengan perjanjian merupakan suatu kewajiban bagi salah satu pihak serta sebagai hak bagi pihak lainnya yang menerima sesuatu tersebut sebagaimana yang didasarkan pada perjanjian para pihak.

Meninjau kembali mengenai definisi perjanjian sebagaimana yang telah disebutkan dalam Pasal 1313 Kitab Undang-Undang Hukum Perdata, dalam pandangan beberapa ahli hukum mengenai definisi perjanjian, dimulai dari pandangan Subekti bahwa perjanjian merupakan "suatu peristiwa di mana seorang berjanji kepada seorang lain atau di mana dua orang itu saling berjanji untuk

3 Subekti, 2010, Hukum Perjanjian, Cetakan kesepuluh, Intermasa, Jakarta, h. 1. 
melaksanakan sesuatu hal". ${ }^{4}$ Menurut Setiawan, perlu kiranya diadakan perbaikan mengenai definisi perjanjian tersebut yaitu :

a. Perbuatan harus diartikan sebagai perbuatan hukum, yaitu perbuatan yang bertujuan untuk menimbulkan akibat hukum;

b. Menambahkan perkataan "atau saling mengikatkan dirinya" dalam Pasal 1313 BW;

c. Sehingga perumusannya menjadi, "perjanjian adalah perbuatan hukum, dimana satu orang atau lebih mengikatkan dirinya atau saling mengikatkan dirinya terhadap satu orang atau lebih." 5

Perjanjian selanjutnya jika dilihat dari segi bentuknya dibedakan menjadi dua macam, yaitu tertulis dan lisan. Perjanjian tertulis adalah suatu perjanjian yang buat oleh para pihak dalam bentuk tulisan, sedangkan perjanjian lisan adalah suatu perjanjian yang dibuat oleh para pihak dalam wujud lisan (cukup kesepakatan para pihak). ${ }^{6}$

$$
\text { Lebih spesifik kepada }
$$

perjanjian lisan, biasanya perjanjian lisan banyak digunakan dalam kegiatan bisnis. Perjanjian lisan pada umumnya diterapkan hanya dengan menggunakan suatu ucapan oleh para pihak. Penggunaan perjanjian lisan juga biasanya dilakukan tanpa disadari oleh para pelaku bisnis, contohnya dalam

4 Agus Yudha Hernoko, 2008, Hukum Perjanjian Azas Proporsionalitas dalam Kontrak Komersial, LaksBang Mediatama, Yogyakarta, h. 14.

5 Ibid.

6 Salim, HS, 2016, Pengantar Hukum Perdata Tertulis (BW), Sinar Grafika, Jakarta, h. 166. perdagangan buah apel antara penjual dan pembeli yang terjadi di pasar tradisional dimana setelah melalui proses tawar menawar, tercipta kesepakatan mengenai harga apel beserta pelaksanaan penyerahan apel oleh penjual kepada pembeli serta pembayaran sejumlah uang oleh pembeli kepada penjual. Pada proses perdagangan buah apel tersebut tidak menggunakan perjanjian tertulis. Harga yang disepakati tidak dituangkan dalam perjanjian secara tertulis melainkan cukup dengan ucapan saja, serta pelaksanaan penyerahan dan pembayaran buah apel tidak menggunakan perjanjian secara tertulis sebagai dasar hukumnya.

Perjanjian dalam bentuk tidak tertulis atau perjanjian lisan pada umumnya cenderung dianggap sebagai perjanjian yang lemah mengingat perjanjian lisan lebih susah untuk dibuktikan karena mudah untuk disangkal oleh pihak yang berjanji jika dibandingkan dengan perjanjian tertulis yang klausulnya tertulis dengan jelas dan disertai tanda tangan para pihak sebagai tanda terjadinya kesepakatan, walaupun pada faktanya perjanjian tertulis juga bisa diingkari oleh para pihak seperti misalnya salah satu pihak tidak mengakui atau menyangkal telah menandatangani suatu perjanjian ataupun salah satu pihak merasa dirinya dalam keadaan terpaksa atau khilaf menandatangani perjanjian.

Perjanjian tidak tertulis atau perjanjian lisan meskipun dianggap lebih lemah kedudukannya dibandingkan dengan perjanjian 
tertulis, bukan berarti perjanjian lisan tidak diakui sebagai perjanjian yang sah. Perjanjian baik itu perjanjian tertulis maupun tidak tertulis jika merujuk kepada Pasal 1320 Kitab Undang-Undang Hukum Perdata, harus memenuhi 4 (empat) syarat dalam menentukan perjanjian tersebut sah atau tidak sah. 4 (empat) syarat tersebut antara lain:

1. Sepakat mereka yang mengikatkan dirinya;

2. Kecakapan untuk membuat suatu perikatan;

3. Suatu hal tertentu;

4. Suatu sebab yang halal.

Pada syarat-syarat tersebut, secara teoritis syarat pertama dan syarat kedua mengenai kesepakatan dan kecakapan tergolong sebagai syarat subyektif, sedangkan syarat ketiga dan syarat keempat mengenai suatu hal dan suatu sebab yang halal tergolong sebagai syarat obyektif. Akibat hukum apabila syarat subyektif tidak terpenuhi maka mengakibatkan perjanjian tersebut dapat dibatalkan, sedangkan apabila syarat obyektif yang tidak terpenuhi maka mengakibatkan perjanjian tersebut batal demi hukum. Hal ini berlaku pula pada bentuk perjanjian tidak tertulis, mengingat keempat syarat sah perjanjian tersebut tidak disyaratkan secara tertulis. Selama bentuk perjanjian tidak tertulis telah memenuhi serta tidak melanggar keempat syarat tersebut, maka perjanjian tersebut sah secara hukum.

Keberadaan perjanjian tidak tertulis juga tidak terlepas pada asas-asas hukum perdata. Melihat pada beberapa asas-asas hukum perdata, perjanjian tidak tertulis dapat berdasar maupun dianalisis pada asas hukum perdata seperti berikut:

A. Asas Kebebasan Berkontrak

Asas kebebasan berkontrak merupakan salah satu dasar keberadaan perjanjian tidak tertulis. Salah satu pilar hukum perjanjian yakni asas kebebasan berkontrak yang secara universal dikenal oleh sistem hukum negara manapun, sebagai prinsip andalan yang mampu menjamin keleluasaan dan ketinggian intensitas kegiatan pasar. Kebebasan berkontrak yang berintikan keleluasaan dalam menentukan bentuk, jenis, dan isi perjanjian serasa tak akan lekang oleh tantangan zaman dan enggan lapuk akibat derasnya kemajuan. Prinsip ini memang merupakan salah satu bias sinar Hak Asasi Manusia yang selalu menjunjung tinggi harkat kehendak individu sebagai makhluk sosial. ${ }^{7}$

Kebebasan berkontrak adalah asas yang esensial, baik bagi individu dalam mengembangkan diri baik di dalam kehidupan pribadi maupun kehidupan sosial kemasyarakatan, sehingga beberapa pakar menegaskan kebebasan berkontrak merupakan bagian dari hak asasi manusia yang harus dihormati. ${ }^{8}$ Kebebasan berkontrak dalam hubungannya dengan membentuk perjanjian, orang tidak dapat dipaksa untuk memberikan

7 H. Moch. Isnaeni, 2013, Perkembangan Hukum Perdata Di Indonesia, Laksbang Grafiika, Yogyakarta, h. 15. (Selanjutnya Disebut H. Moch Isnaeni II)

8 Aries Harianto, 2016, Hukum Ketenagakerjaan; Makna Kesusilaan dalam Perjanjian Kerja, Laksbang Pressindo, Yogyakarta, h. 198. 
sepakatnya. Sepakat yang diberikan dengan paksa adalah contradictio interminis. Adanya paksaan menunjukkan tidak adanya sepakat yang mugkin dilakukan oleh pihak lain. Kesepakatan memberkan pilihan kepada para pihak, untuk setuju atau tidak setuju mengikatkan diri pada perjanjian dengan akibat hukumnya. ${ }^{9}$

Berkenaan dengan ruang lingkup asas kebebasan berkontrak, menurut Sutan Remi Sjahdeini asas kebebasan berkontrak menurut hukum perjanjian Indonesia meliputi ruang lingkup :

a. Kebebasan untuk membuat atau tidak membuat perjanjian.

b. Kebebasan untuk memilih pihak dengan siapa ia ingin membuat perjanjian.

c. Kebebasan untuk menentukan atau memilih kausa dari perjanjian yang akan dibuatnya.

d. Kebebasan untuk menentukan objek perjanjian.

e. Kebebasan untuk menentukan bentuk suatu perjanjian.

f. Kebebasan untuk menerima atau menyimpangi ketentuan undang-undang yang bersifat opsional (aanvullend, optional). ${ }^{10}$

Asas kebebasan berkontrak sebagaimana dalam huruf e, kebebasan berkontrak memberikan kebebasan kepada para pihak dalam membentuk perjanjian baik itu perjanjian tertulis maupun perjanjian tidak tertulis. Hal ini menunjukkan tidak adanya keharusan atau mewajibkan para

9 Tuti Rastuti, 2016, Aspek Hukum Perjanjian Asuransi, Medpress Digital, Yogyakarta, h. 44.

${ }^{10}$ Agus Yudha Hernoko, Op. Cit., h. 110. pihak menyatakan kesepakatannya dalam suatu perjanjian tertulis.

Kebebasan

berkontrak merupakan asas yang memberikan kebebasan bagi para pihak agar tidak terjadi intervensi dari salah satu pihak dalam membuat perjanjian. Kebebasan yang diberikan bukan berarti tanpa adanya suatu batasan, karena apabila tidak dibatasi maka akan melanggar hak, kepentingan, maupun Hak Asasi Manusia dari pihak yang diajak untuk membuat perjanjian. Merujuk pada ketentuan Pasal 1337 dan Pasal 1339 Kitab Undang-Undang Hukum Perdata, batasan pada suatu kebebasan berkontrak adalah tidak bertentangan dengan UndangUndang, kesusilaan, ketertiban umum, kepatutan, serta kebiasaan.

B. Asas facta sunt servanda

Asas ini berkenaan dengan daya mengikatnya sebuah perjanjian yang telah dibentuk dan disepakati oleh para pihak. Pengaturan prinsip facta sunt servanda dalam perundangundangan terletak pada Pasal 1338 ayat (1) Kitab Undang-Undang Hukum Perdata yang menyatakan "semua perjanjian yang dibuat secara sah berlaku sebagai undangundang bagi mereka yang membuatnya".

Pada ketentuan Pasal 1338 ayat (1) Kitab Undang-Undang Hukum Perdata tersebut, keberadaan asas facta sunt servanda dibuktikan pada keberlakuan suatu perjanjian yang dibuat para pihak yakni berlaku sebagai Undang-Undang. Keberlakuan perjanjian sebagai undang-undang ini berakibat bahwa perjanjian merupakan dasar hukum 
bagi para pihak. Mengikatnya suatu perjanjian juga berlaku pada perjanjian tidak tertulis. Perjanjian tidak tertulis juga mengikat sebagai undang-undang bagi para pihak yang membuat, selama perjanjian tidak tertulis tersebut merupakan perjanjian yang sah sebagaimana dalam Pasal 1320 Kitab UndangUndang Hukum Perdata. Mengikatnya suatu perjanjian sebagaimana dalam asas pacta sunt servanda dititikberatkan pada pelaksanaan perjanjian, dimana pelaksanaan perjanjian tersebut agar tidak menyimpang pada klausul perjanjian yang telah disepakati baik itu tertulis atau tidak tertulis.

\section{Asas itikad baik}

Asas itikad baik merupakan salah satu asas yang sangat berperan penting terutama dalam pelaksanaan perjanjian tidak tertulis. Berbicara mengenai asas itikad baik, asas ini tercantum dalam Pasal 1338 ayat (3) Kitab Undang-Undang Hukum Perdata yang menyatakan bahwa "suatu perjanjian harus dilaksanakan dengan itikad baik". Berdasarkan pada ketentuan tersebut, dihubungkan pula dengan pandangan Wirjono Prodjodikoro yang membagi itikad baik menjadi dua macam yakni :

1. Itikad baik pada waktu mulai berlakunya suatu hubungan hukum

2. Itikad baik pada waktu pelaksanaan hak-hak dan kewajiban-kewajiban yang termaktub dalam hubungan hukum itu. ${ }^{11}$

11 Osgar S Matompo dan Moh. Nafri Harun, 2017, Pengantar Hukum Perdata, Setara Press, Malang, h. 119.
Melihat kembali pada ketentuan Pasal 1338 ayat (3) Kitab Undang-Undang Hukum Perdata, serta dengan dikaitkan pula pada pembagian itikad baik sebagaimana disebutkan Wirjono Prodjodikoro, itikad baik dalam Undang-Undang hanya ditekankan pada pelaksanaan suatu perjanjian saja. Jika melihat tahapan perjanjian dimulai dari proses pembuatan suatu perjanjian hingga pengakhiran suatu perjanjian, membutuhkan adanya itikad baik sehingga perjanjian dapat dilaksanakan dengan baik, serta dapat menciptakan hubungan baik meskipun perjanjian tersebut telah berakhir. Oleh karena itu, asas itikad baik seharusnya tidak hanya ditekankan pada pelaksanaan perjanjian saja, melainkan pula ditekankan dalam mendukung asas konsensualisme terkait pembentukan suatu kesepakatan, serta dalam pengakhiran suatu perjanjian.

Mengingat kembali pada keberadaan perjanjian tidak tertulis jika dihubungkan dengan asas itikad baik ini, pada dasarnya perjanjian tidak tertulis segala klausul yang disepakati hanya secara lisan. Kesepakatan secara lisan ini tentu mudah untuk diingkari oleh salah satu pihak sehingga memicu permasalahan yang mengakibatkan tidak dapat terlaksananya hak dan kewajiban sebagaimana mestinya. Oleh karena itu, asas itikad baik sangat dibutuhkan dalam pelaksanaan perjanjian terutama pada perjanjian tidak tertulis sehingga pelaksanaan perjanjian sebagaimana yang telah disepakati walaupun kesepakatan tersebut hanya secara lisan, namun dapat terlaksana dengan baik. 
D. Asas konsensualisme

Asas konsensualisme menentukan bahwa suatu perjanjian yang dibuat antara dua atau lebih orang telah mengikat sehingga telah melahirkan kewajiban bagi salah satu atau lebih pihak dalam perjanjian tersebut, segera setelah orang-orang tersebut mencapai kesepakatan atau konsensus. ${ }^{12}$ Penekanan asas konsensualisme terletak pada kesepakatan sebagaimana dalam pasal 1321 Kitab Undang-Undang Hukum Perdata. Kesepakatan dalam asas konsensualisme menentukan sah perjanjian dalam syarat subyektif. Mengacu pada Kitab UndangUndang Hukum Perdata pada Pasal 1321, kesepakatan tidak diperkenankan adanya unsur :
a. Kekhilafan;
b. Paksaan;
c. Penipuan.

Asas konsensualisme ini jika dihubungkan dengan perjanjian tidak tertulis, pada dasarnya perjanjian tidak tertulis segala klausul yang disepakati tersebut hanya secara lisan atau ucapan saja, sehingga bisa saja terjadi kekhilafan, paksaan, maupun penipuan. Oleh karena itu, keberadaan asas konsensualisme ini untuk mencegah agar para pihak dalam membentuk suatu kesepakatan tidak diperkenankan adanya kekhilafan, paksaan, maupun penipuan.

\section{Keunggulan dan kelemahan terhadap pembentukan dan pelaksanaan perjanjian tidak tertulis}

12 Gunawan Widjaja, 2007, Memahami Prinsip Keterbukaan Dalam Hukum Perdata, Raja Grafindo Persada, Jakarta, h. 263.
Perjanjian tidak tertulis atau dikenal pula dengan istilah lainnya yakni perjanjian lisan, dalam kegiatan dan kebiasaan bisnis, perjanjian tidak tertulis sering digunakan. Perjanjian tidak tertulis jika dibandingkan dengan perjanjian tertulis, dalam hal memberikan rasa aman serta membuktikan kesepakatan tentu perjanjian tertulis lebih unggul jika dibandingkan dengan perjanjian tidak tertulis. Apabila membandingkan penggunaan perjanjian tertulis dan peranjian tidak tertulis, justru perjanjian tidak tertulis lebih sering digunakan baik secara sadar maupun tanpa disadari terutama bagi kalangan masyarakat tradisional dalam melakukan kegiatan bisnis.

Perjanjian tidak tertulis sebagai perjanjian yang dipilih dalam melakukan suatu kegiatan bisnis mengingat perjanjian tidak tertulis lebih mudah atau tidak membutuhkan waktu yang lama dalam menciptakan kesepakatan. Jika dibandingkan dengan perjanjian tertulis, proses mencapai kesepakatan pada perjanjian tertulis membutuhkan waktu yang sangat lama yakni dimulai dari para pihak melaksanakan suatu negosiasi, kemudian konsep-konsep kesepakatan dari negosiasi tersebut dituangkan dalam suatu perjanjian tertulis. Menulis suatu perjanjian pula membutuhkan waktu yang cukup. Konsep kesepakatan yang telah dibuat secara tertulis tersebut kemudian diperiksa kembali oleh para pihak sebelum ditandatangani. Apabila ada hal yang masih kurang sesuai dalam konsep kesepakatan tertulis tersebut, selanjutnya 
perjanjian tersebut diperbaiki kembali hingga perjanjian tersebut sesuai dengan maksud para pihak. Memperbaiki perjanjian juga membutuhkan waktu yang cukup, hingga setelah perjanjian tersebut selesai diperbaiki, selanjutnya perjanjian tersebut ditandatangani oleh para pihak. Hal ini berbeda jika dibandingkan dengan perjanjian tidak tertulis. Pada perjanjian tidak tertulis, hanya cukup dengan negosiasi secara lisan saja dengan dasar kepercayaan dalam mencapai kesepakatan. Apabila telah tercapai kesepakatan, para pihak dapat melaksanakan secara langsung segala hal yang telah disepakati tersebut.

Berdasarkan pada perbandingan perjanjian tertulis dan perjanjian tidak tertulis dalam proses mencapai kesepakatan, perjanjian tidak tertulis lebih efisien waktunya dalam mencapai kesepakatan jika dibandingkan dengan perjanjian tertulis. Perjanjian tidak tertulis lebih mengutamakan kepercayaan dalam pembentukan dan pelaksanaan perjanjiannya, sedangkan perjanjian tertulis lebih mengutamakan kehatihatian dalam pembentukan dan pelaksanaan perjanjiannya.

Pada kegiatan bisnis, rasa kepercayaan sangat dibutuhkan dalam menciptakan hubungan yang baik. Rasa kepercayaan yang tinggi tentunya pula harus disertai dengan itikad yang baik. Itikad baik sangat berpengaruh terhadap kepercayaan mengingat itikad baik berkaitan dengan niat serta perbuatan dalam melakukan sesuatu dengan baik, sehingga ketika seseorang dalam menjalin hubungan tidak disertai dengan itikad yang baik pula dapat mengakibatkan hilangnya rasa kepercayaan terutama dalam melaksanakan suatu perjanjian.

Pada pelaksanaan perjanjian baik itu perjanjian tertulis maupun perjanjian tidak tertulis, dapat terjadi upaya penambahan atau pengurangan klausul perjanjian yang dikenal pula dengan istilah addendum. Addendum pada suatu perjanjian tentu membutuhkan kesepakatan antara para pihak yang terikat pada perjanjian tersebut. Salah satu keunggulan perjanjian tidak tertulis ini pula yakni pada proses addendum tidak membutuhkan waktu lama jika dibandingkan dengan perjanjian tertulis. Hal ini karena sebagaimana yang telah dipahami bahwa kepercayaan merupakan dasar utama dalam membentuk maupun melaksanakan perjanjian tidak tertulis.

Penggunaan perjanjian tidak tertulis jika dibandingkan dengan perjanjian tertulis, peluang terjadinya sengketa pada perjanjian tidak tertulis lebih tinggi dibandingkan dengan perjanjian tertulis. Hal ini tentunya disebabkan karena segala klausul yang disepakati dalam perjanjian tidak tertulis hanya berupa hal-hal yang diucapkan secara lisan saja oleh para pihak. Klausul perjanjian yang hanya diucapkan secara lisan saja atau tanpa adanya suatu tulisan lebih mudah untuk diingkari atau tidak diakui oleh salah satu pihak. Bahkan apabila sengketa tersebut berlanjut hingga pada proses litigasi, pembuktian dari klausulklausul perjanjian tidak tertulis lebih sulit dibuktikan jika 
dibandingkan dengan perjanjian tertulis. Pembuktian adanya perjanjian tidak tertulis serta segala klausul yang disepakati hanya bergantung pada pengakuan dari para pihak yang membuat dan melaksanakan perjanjian tersebut. Berbeda dengan perjanjian tertulis yang menggunakan perjanjian yang telah dibuat dalam bentuk tertulis untuk menguatkan pengakuan dari pihak yang bersengketa.

Berdasarkan pada segala hal yang telah dijabarkan tersebut, maka dapat disimpulkan bahwa perjanjian tidak tertulis atau perjanjian lisan memiliki keunggulan dan kelemahan. Adapun keunggulan dan kelemahan perjanjian tidak tertulis antara lain :

a. Keunggulan perjanjian tidak tertulis :

1. Tidak membutuhkan waktu yang panjang dalam mencapai kesepakatan

2. Pembentukan dan pelaksanaan perjanjian didasarkan pada kepercayaan masingmasing pihak.

3. Penambahan atau pengurangan klausul perjanjian dapat dilakukan secara cepat.

4. Mempererat rasa kepercayaan dalam interaksi serta kegiatan bisnis.

5. Adanya rasa kepercayaan mampu menciptakan hubungan yang baik bahkan setelah berakhirnya perjanjian b. Kelemahan perjanjian tidak tertulis :

1. Klausul perjanjian mudah diingkari atau tidak diakui karena tidak dinyatakan secara tertulis.

2. Kurang aman ketika digunakan sebagai pembuktian dalam proses litigasi karena hanya bergantung pada pengakuan dari para pihak yang membuat dan melaksanakan perjanjian.

Berdasarkan pada kelemahankelemahan perjanjian tidak tertulis tersebut, adapun upaya yang dapat dilakukan untuk menutupi kelemahan perjanjian tidak tertulis yakni dengan cara menyiapkan saksi minimal 2 (dua) orang untuk menyaksikan kesepakatan para pihak dalam membentuk perjanjian tidak tertulis. Segala transaksi yang terjadi dalam perjanjian tidak tertulis juga sebaiknya disertai dengan kwitansi atau nota pembayaran maupun tanda terima demi menghindari terjadinya sengketa di kemudian hari.

\section{Kesimpulan}

Perjanjian tidak tertulis merupakan perjanjian yang sah sebagaimana dalam kajian hukum perdata selama dibuat tidak bertentangan dengan Pasal 1320 Kitab Undang-Undang Hukum Perdata. Keberadaan perjanjian tidak tertulis melekat pada prinsip kebebasan para pihak yang membentuk dan melaksanakan perjanjian sebagaimana dalam asas kebebasan berkontrak serta didukung pula pelaksanaannya 
pada asas-asas hukum perjanjian lainnya.

Perjanjian tidak tertulis memiliki keunggulan dan kelemahan. Keunggulan perjanjian tertulis lebih kepada efisien waktu dalam membentuk dan melaksanakan perjanjian serta adanya kepercayaan dalam membentuk dan melaksanakan perjanjian. Kelemahan perjanjian tidak tertulis terletak pada resiko terjadinya sengketa yakni terkait pembuktian segala hal yang telah disepakati.

\section{Saran}

Penggunaan perjanjian tidak tertulis pada prakteknya sebaiknya dengan cara menyiapkan saksi minimal 2 (dua) orang dalam proses pembentukan perjanjian serta selalu mempersiapkan nota pembayaran, kwitansi, maupun tanda terima dalam setiap transaksi yang terjadi dalam pelaksanaan perjanjian.

\section{Daftar Pustaka}

Harianto, Aries, 2016, Hukum Ketenagakerjaan; Makna Kesusilaan dalam Perjanjian
Kerja, Laksbang Pressindo, Yogyakarta.

Hernoko, Agus Yudha, 2008, Hukum Perjanjian Azas Proporsionalitas dalam Kontrak Komersial, LaksBang Mediatama, Yogyakarta.

Is, Muhamad Sadi, 2017, Pengantar Ilmu Hukum, Kencana, Jakarta.

Isnaeni, H. Moch., 2013, Perkembangan Hukum Perdata Di Indonesia, Laksbang Grafiika, Yogyakarta. 2016, Perjanjian Jual Beli, Refika Aditama, Bandung.

Matompo, Osgar S dan Moh. Nafri Harun, 2017, Pengantar Hukum Perdata, Setara Press, Malang.

Rastuti, Tuti, 2016, Aspek Hukum Perjanjian Asuransi, Medpress Digital, Yogyakarta.

Salim, HS, 2016, Pengantar Hukum Perdata Tertulis (BW), Sinar Grafika, Jakarta.

Subekti, 2010, Hukum Perjanjian, Cetakan kesepuluh, Intermasa, Jakarta.

Widjaja, Gunawan, 2007, Memahami Prinsip Keterbukaan Dalam Hukum Perdata, Raja Grafindo Persada, Jakarta. 